\title{
DIALÉTICA NEGATIVA E MATERIALISMO DIALÉTICO: DA SUBJETIVIDADE DECOMPOSTA A OBJETIVIDADE PERVERTIDA
}

\author{
Silvia Rosa da Silva Zanolla* \\ silviazanollaufg@hotmail.com
}

\begin{abstract}
RESUMO $O$ trabalho apresenta uma discussão polêmica, complexa e enigmática para a teoria do conhecimento: a elaboração da dialética negativa na concepção da teoria crítica frankfurtiana - sobretudo, adorniana - na interface com a dialética materialista, do marxismo. Do estudo emerge uma proposta de reestruturação do universo objetivo no sentido de indicar elementos subjetivos - por intermédio da teoria psicanalítica - como possibilidade de superação do estado da alienação ampla: intelectual, política, cultural e humana. Trata de confrontar aspectos metodológicos, teóricos e subjetivos em âmbito social amparado por uma perspectiva crítica. As contribuições, para além dos embates entre o idealismo clássico e o materialismo moderno, atravessam, entre outras, as perspectivas heideggeriana, hegeliana, kantiana, freudiana, marxiana e adorniana, visando apresentar fundamentos epistemológicos e teóricos que embasam a teoria crítica ao tempo que identifica diferenças e convergências entre o materialismo sócio-histórico dialético e a dialética negativa; componentes relevantes para compreender a incursão desta teoria no âmbito das diversas áreas do conhecimento.
\end{abstract}

Palavras-chave Dialética negativa, Teoria crítica e marxismo, Subjetividade.

* Universidade Federal de Goiás (UFG). Artigo recebido em 1ㅇo9/2014 e aprovado em 15/05/2015. 
ABSTRACT This paper presents a controversial, complex and enigmatic discussion for knowledge theory: the development of the concept of negative dialectic Frankfurtian critical theory - especially Adornian - on the interface with the materialist dialectics of Marxism. From this study emerges a restructuring proposal of the objective universe as to indicate subjective elements - through psychoanalytic theory - as a possibility to overcome the alienation state: intellectual, political, cultural and human. It is about confronting methodological, theoretical and subjective aspects of the social field supported by a critical perspective. The contributions, beyond the clashes between classical idealism and modern materialism cross, among others, the Heidegger, Hegel, Kant, Freud, Marx and Adorno's perspectives, aiming to present epistemological and theoretical foundations that underlie critical theory at the time that it identifies differences and convergences between historical social dialectic materialism and the negative dialectic; relevant components to understand the incursion of this theory in the context of various areas of knowledge.

Keywords Negative Dialectic, Critical Theoryand Marxism, Subjectivity.

\section{Teoria crítica frankfurtiana: dialética negativa e fundamentos}

Parece contraditório ou pejorativo no primeiro momento definir a dialética acrescida do termo 'negativa'. Entretanto, essa definição, no âmbito da teoria crítica adorniana, encontra sua razão de ser em grande profundidade. Em 1966, na obra "Dialética Negativa", o filósofo e sociólogo Theodor Adorno apresenta um estudo epistemológico substancial, referente ao conceito da dialética perpassado pela tradição da teoria do conhecimento e seus efeitos epistemológicos, práticos e teóricos, sobretudo, na interface com as clássicas dicotomias: materialismo e idealismo, sujeito e objeto. Embora a discussão original tenha traduzido um diálogo com o existencialismo heideggeriano e seus pensadores afins (destacando-se Husserl, Popper, Wittgenstein e Sartre), Adorno privilegia, as vertentes kantiana, hegeliana, marxiana e freudiana na perspectiva de denunciar a incompreensão destes fundamentos que levam estudiosos tanto da perspectiva positivista quanto da existencialista a fomentarem o relativismo metafísico em prejuízo à compreensão do lugar que ocupam o idealismo e o materialismo na discussão (Adorno, 1984). Muito embora o debate se dê no plano teórico, subjacente a isso, carece explicitar o 
momento em que se deu, na visão de Adorno, certo diagnóstico da época em que se pensou a dialética negativa (Nobre, 1999).

Este debate acontece como desdobramento de um contexto propício para se questionarem os rumos do capitalismo - tardio ou não - ancorado em uma proposta nova relativa à visão de homem permeada pelos ventos do liberalismo após a Segunda Guerra Mundial (Adorno, 1984). Desse modo, seria arbitrário adentrar na discussão sobre as motivações que levaram à ideia da dialética negativa, sem antes mencionar os fundamentos do livro "Dialética do Esclarecimento", de 1947, que, embora uma obra conjunta com Horkheimer, a priori, lança bases teóricas que influenciarão o arcabouço teórico geral de Adorno de modo coerente.

Para Nobre e Marin (2012), a tessitura da "Dialética do Esclarecimento" considera essenciais alguns fatores, destacando-se, sobretudo: o prenúncio de uma ontologia com vertentes antropológicas e a urgência de um olhar interdisciplinar sobre o legado adorniano (p. 101). Na "Dialética do Esclarecimento", a propositura é acompanhada por certa perda da centralidade na economia política e uma crise de identidade no aspecto humano político. A preocupação com o fator humano enquanto possibilidade imanente de ir além das explicações econômicas para entender a ideologia revela-se, segundo Nobre e Marin (2012), em uma perspectiva antropológica e de caráter interdisciplinar. O que, segundo os autores, encontra, sobretudo na Psicanálise, uma fonte inesgotável de conceitos que possibilitam refletir sobre o homem da "pseudo-individualidade". Assim, a noção da relação entre dialética e trabalho é acrescida pela ambivalência psicanalítica da autopreservação versus autodestruição, natureza versus criação; permeada pela angústia do conflito: o trabalho representa a repressão como condição para a liberdade ou a dominação. Essa base se estende à obra "Dialética Negativa" de Adorno (1984), em que se constata também uma coerência conceitual e (a)estética entre conteúdo e forma. Para Silva (2009):

Pode-se, por exemplo, perguntar por que a dialética negativa se afasta de todos os temas estéticos, o que, aliás, não deixaria de ter um impacto sobre a tradição, uma vez que parte considerável da literatura secundária procura esclarecer essa relação. Pode-se procurar entender como é possível que a consequência lógica atue contra o princípio de unidade e o domínio do conceito, o que é agravado pelo fato de o pensamento de Adorno ser fundamentalmente erguido ao largo dos conceitos rigidamente definidos. Pode-se questionar o sentido de atribuir a algo do âmbito da lógica um sentido que lhe é avesso, o de encanto (p. 56).

Para este autor, a dialética negativa preconiza conceitualmente uma espécie de "antissistema", o que faz com que o conteúdo epistemológico e 
filosófico seja coerente com seu "formato" (a)estético. Desde a discussão em torno da "Dialética do Esclarecimento", àquela que preconiza a elaboração da Dialética Negativa, seguramente o estilo adorniano enfrenta desafios em uma razão estipulada pelo formato tradicional conceitual do saber. Nesse sentido, importa que o autor enfrente o véu da dialética fetichizada, idealizada, demonstrando sua insuficiência perante a essência da dialética imanente e inesgotável.

Longe de ser apenas redundante e pejorativo, o termo, dialética negativa mantém fidelidade ao processo dinâmico e contraditório que envolve o conceito, a sociedade e o homem, ao tempo que compõe um conjunto de fatores substancialmente filosóficos e epistemológicos que dispõem prestar contas ante o risco de banalização da própria filosofia fenomenológica e, sobretudo, do idealismo (tanto kantiano quanto hegeliano) pelo pensamento metafísico e hermenêutico (Adorno, 1984, pp. 13-16). Assim, para o autor, está em questão a penúria do conhecimento revisionista neo-hegeliano e, sobretudo, neokantiano que, contraditoriamente, arrisca relativizar o idealismo e o que tem de mais precioso: contradições que revelam identidade, fazendo emergir elementos de denúncia aos limites da prática e seu empobrecimento, a idealização da dialética e da práxis fetichizadas (Adorno, 1995). A "dinâmica" resvala em princípios regidos por antinomias kantianas à medida que estas confrontam a racionalidade ante a realidade, de modo a compor ideias referentes às instâncias universais e particulares, que atuam em duplo revés: sujeito e objeto, essência e aparência, juízo sintético e juízo analítico; compondo a proposição (a)dialética. Nesse processo, na relação entre ação e reflexão (inflexão) identificam-se elementos ligados à representação e seus riscos de sobrepujar a realidade, por proposições de argumentos práticos da verdade (Adorno, 1995). Essa elaboração, como diria Kant, pode revelar o potencial risco de inebriar contradições inerentes à própria racionalidade que rege as ações: o perigo do dogmatismo diante do empirismo que reduz tudo à experiência por medo do próprio abstracionismo (Kant, 2003).

À parte a discussão entre o ser e o existir, o sujeito cognoscitivo e o objeto cognoscente e suas interpretações vinculadas à metafísica, antecede uma polêmica histórica que diz respeito às dicotomias entre idealismo versus materialismo e abstracionismo versus idealismo. Isso adverte contra o risco de banalizar o pensamento kantiano fadando-o à metafísica existencialista que traduz a banalização histórica a que se sujeita o idealismo clássico; obstaculiza as contradições inerentes à relação entre teoria e prática, experiência e ação pragmática, relação esta que resvala na relação entre positivismo e abstracionismo; constituindo uma aporia enfrentada como pedra angular de 
dentro do arcabouço teórico da teoria crítica de Adorno ante uma apropriação geral da perspectiva sócio-histórica do materialismo dialético marxiano, que tende a banalizá-lo e o projetar, em nome da ação política, ao patamar do senso comum (Zanolla, 2007).

As diferenças conceituais entre as abordagens do materialismo histórico dialético de Engels e Marx e a dialética negativa de Adorno, estas basilares para a teoria crítica frankfurtiana, confrontam o abstracionismo relativista amparadas na história da sociedade, da constituição humana e do conhecimento como um todo; emergindo fatores estruturais objetivos e subjetivos de sua composição. A celeuma instaurada pela visão hermenêutica do existencialismo, criticada por Adorno em torno da dialética, não exaure riscos e limites ao abstraimento da realidade do materialismo histórico, antes, arrisca relativizar a relação entre sujeito e objeto, ao tempo que descaracteriza o sentido da contradição em termos conceituais e práticos: "A dialética não é um ponto de vista" (Adorno, 1984, p. 13). Essa advertência retoma a complexidade da dialética perpassada por elaborações clássicas como de Kant (2003), para quem os objetos representam sentidos além de seus conceitos e imagens; o que, por si, segundo Adorno (1995), exige trato rigoroso e histórico indispensável para compreender o percurso que se desdobra ao "status da dialética materialista" e, consequentemente, à "dialética negativa". Para tanto, necessário se faz compreender as motivações que levaram à inserção de Adorno na Escola de Frankfurt, bem como a apropriação da Psicanálise como elemento contraditoriamente relevante à consolidação da dialética negativa como ampliação da dialética sócio-histórico-materialista (Zanolla, 2007).

Em 1971, o filósofo Horkheimer, aliado de Adorno, em carta ao historiador Martin Jay, confidenciou a razão principal que levou à criação do Instituto de Investigação Social em 1923, mais tarde denominado Escola de Frankfurt. Segundo o autor, naquela época, um grupo com formação diferente e interessado em teoria social uniu-se em torno da convicção de que a "formulação do negativo" era mais importante que suas carreiras acadêmicas; o que o motivou, sobretudo, à aproximação com a perspectiva da dialética materialista e sua crítica à sociedade. Para Horkheimer, o objetivo dos estudos dos frankfurtianos era dar uma resposta às indagações marxistas sobre as possibilidades da transição revolucionária em meio ao dogmatismo e ao desafio dos sistemas políticos que, aparentemente, se rendiam a "apelações do absoluto" - no sentido da conciliação de elementos opostos em termos teóricos e políticos -, que, de qualquer maneira, ligavam-se a um tipo de "apelação enfática da verdade", uma positivação de ideias e ações para além do tradicional positivismo (Jay, 1973, pp. 9-10). Assim, retoma-se 
Adorno e Horkheimer na obra "Dialética do Esclarecimento" (1985): "O que nos propuséramos era, de fato, nada menos do que descobrir por que a humanidade, em vez de entrar em um estado verdadeiramente humano, está se afundando em uma espécie de barbárie" (p. 11). Devido ao fracasso da ideia de um sujeito revolucionário em sentido amplo, a teoria crítica frankfurtiana concebe eleger, além do universo objetivo, fatores subjetivos que prestem contas dos impeditivos à verdadeira revolução social e humana, mudança esta, cada vez mais, "relegada às calendas gregas" (Adorno, 1995).

Para Nobre (1999), é preciso investigar não apenas a possibilidade da filosofia, mas as condições da crítica imanente defendida por Adorno, com a intenção de estabelecer o sentido do seu percurso intelectual e identificar a identidade e legitimidade de sua obra à parte do arcabouço geral frankfurtiano. A preocupação com aspectos subjetivos na compreensão da realidade advém de um olhar incomum e polêmico acerca dos processos alienantes que regem a sociedade. Daí a perda da centralidade no aspecto econômico como elemento de contraste (Nobre; Marin, 2012). Assim, Adorno alerta para o perigo de transformar interpretações subjetivistas em pontos de vista determinados por identificações do pensamento adequadas à realidade deliberada (Adorno, 1995). Confronta a idealização da relação clássica entre universal e particular como prenúncio do embate teórico e prático entre sujeito e objeto. Dinâmica esta que é histórica e, a priori, justifica análises realizadas acerca de qualquer fenômeno a partir da teoria do conhecimento (Adorno, 1995, p. 181). A totalidade conceitual, (a)estética, aparece como uma ilusão a ser superada na sua aparência: "Pensar quer dizer identificar" (aprisionar), e ainda, "A contradição é o não idêntico" (Adorno, 1984, p. 15).

Para Nobre (1999), o mérito da "Dialética Negativa" está em repensar criticamente a relação entre "exposição e coisa", forma e conteúdo, subjetividade e objetividade; fundamental para um pensamento que pretende libertar a dialética de sua natureza conceitual afirmativa. Ideia esta que em Adorno, coerentemente, resvala na relação contraditória entre sujeito e objeto. A não identidade do presente torna-se pressuposto para uma futura identidade. Para Nobre (1999), a dialética negativa apresenta o princípio da não identidade no qual a crítica. $\mathrm{O}$ aspecto conceitual deve sempre ser identificado como contraditório e passível de uma leitura imanente da relação entre sujeito e objeto.

Nesse sentido, o investimento em estudos sobre a subjetividade faz jus ao pensamento hegeliano, inaugura uma "fenomenologia caracterizada pelo pensamento inimigo da positividade, como um princípio negativo". O vir a ser "prenuncia-se a partir do ser" (Adorno, 1984, p. 46). Para Adorno, a 
decadência do indivíduo ideal é permeada pela indiferença em relação ao sentido do sujeito (ente) e do ser como "quintessência do indivíduo" (1995, p. 186). Reside aí a fragilidade da ideia de identidade do sujeito revolucionário: o delírio de seu potencial transformador como impeditivo real de transformação. Funda-se o sentido da pseudoindividualidade. Desse modo, ser e sujeito diferem em termos materialistas, idealistas, metafísicos e existencialistas. O sujeito fracassa porque é demasiado subjetivado em um contexto carente de objetividade, portanto de subjetividade real, o que o faz coisificado por exigência do "pecado original da metafísica objetivante" (Adorno, 1984, p. 70). Pelo processo de alienação, ocorre uma inversão de sentidos. A objetividade se subjetiva e vice-versa, traduzindo uma dinâmica que, pela mediação cega, relativiza ambas as instâncias, consolida a coisificação humana pela idealização do objeto, qualquer que seja.

Diante das contradições e do predomínio da subjetividade "histórico objetificante", em várias de suas obras, sobretudo na "Dialética Negativa", Adorno recorre à psicologia freudiana para refletir acerca da cega e idealizada realidade, que, segundo ele, é desprovida de sujeitos reais. O princípio da não identidade remete à necessidade de desmistificação do "ser sujeito da compreensão absoluta" (1984, p. 84). A identidade fetichizada determina a forma originária da ideologia amparada racionalmente pela Psicologia.

\begin{abstract}
A Psicologia, apesar de parecer oposta ao universal, cede, ante sua pressão, aos núcleos da interioridade e neste sentido, não é um constituinte da realidade, senão um produto. No entanto, tanto o objetivismo dialético como o positivista são tão míopes como superiores frente a ela. Desde o momento em que a objetividade dominante é inadequada objetivamente aos indivíduos, a única forma de realizar-se é através destes, portanto, psicológica (Adorno, 1984, p. 350).
\end{abstract}

Uma vez que a Psicologia se apresenta como área do conhecimento a acrescentar a discussão da subjetividade como elemento inerente à capacidade de o sujeito superar a condição conformista (Adorno, 1955) e ainda, apesar das críticas à Psicologia em geral, cabe à psicanálise, como área do saber psicológico, por sua especificidade, representar uma "psicologia social mais crítica" (Freud, 1973a). "Mais que colaborativa, a psicanálise freudiana, destrói tão a fundo a aparência da individualidade, que estes só podem resistir em termos filosóficos e sociológicos" (Adorno, 1984, p. 350). Isso, obrigatoriamente, retoma mais uma vez o pensamento de Kant, autor privilegiado por Freud, que colabora para a elaboração dos conceitos de consciente e inconsciente, remanescentes dos conceitos de juízo sintético e analítico; o que retoma contraditoriamente, por sua vez, a natureza do ser hegeliano: "Certamente, o antipsicologismo hegeliano descobriu a prioridade 
empírica do socialmente universal, a mesma que Durkheim expressaria anos depois solidamente sem influência da reflexão dialética" (1984, p. 350).

Essa visão peculiar acrescenta à dialética negativa contribuição aos estudos da subjetividade e ao materialismo histórico dialético. Não obstante, para Marx e Engels (1999), fugir ao abstracionismo do idealismo filosófico por meio da abordagem materialista seria pressuposto básico para compreender os mecanismos culturais e políticos de dominação. Assim, as relações produtivas resumem a ideia de subjetividade: "A essência subjetiva da propriedade privada, é a propriedade privada como atividade, sendo para si, como sujeito, como pessoa, é o trabalho" (p. 85). Em contrapartida, para Adorno, o risco maior da negação do subjetivismo em nome do objetivismo é a objetificação da subjetividade como elemento ideológico. Ou seja, o fetiche da práxis, em que o sujeito se apropria da dialética, o que faz com que se confunda experiência com realidade. Na prática, isso acontece com atividades ligadas à militância (ativismo irrefletido), artísticas, políticas, científicas e intelectuais; qualquer ação que envolva a elaboração pelo trabalho (Adorno, 1995).

Os fatores subjetivos do âmbito da Psicologia motivaram Adorno a estudar as particularidades da personalidade como um padrão ideológico articulado psiquicamente pela sociedade e pela cultura. Embora fosse crítico do conhecimento conservador, Adorno não poderia ignorar categorias da Psicologia tradicional como escalas de avaliações gerais do comportamento, diagnósticos, dados referentes a atitudes e elementos de classificação da personalidade (Adorno, 1965). Não obstante, percebe-se coerência nos motivos que levaram Adorno a se voltar para estudos subjetivos que pudessem contribuir para compreender as contradições da realidade e do próprio materialismo.

Ciente dos limites inerentes à consolidação da subjetividade no contexto da Revolução Industrial, demarcada por fatores históricos determinantes das condições objetivas vinculadas às relações produtivas, Adorno (1995) identifica uma realidade específica - determinada pela luta de classes em um contexto em que a dominação pré-liberal não contava ainda com uma indústria cultural tão amplamente estruturada, como no século XX. Supõe-se, com base nas pesquisas de Adorno (1955), que os meios objetivos utilizados para tentar romper com a alienação foram insuficientes para modificar a estrutura da personalidade do sujeito alienado, coisificado e fascista em potencial; além disso, as relações produtivas emergem resultantes de elementos também psíquicos (desejos, necessidades, emoções, sentimentos, crenças e tabus), de um homem que adere facilmente às ideologias. 
Para Adorno e Horkheimer (1985), desde a "Dialética do Esclarecimento", a dominação racional administrada não encerra a capacidade do sujeito de superar a situação ideológica por ela e em meio a ela. Essa contradição perpassou o trabalho dos frankfurtianos e encontra coerência na crítica à mistificação da dialética tanto em termos idealistas quanto materialistas, atingindo a categoria de práxis. Demonstra isso insuficiência de elementos teóricos tradicionais para compreender a ação política enquanto manifestação do desejo da dominação do e pelo homem moderno. Por esses argumentos, é impossível compreender a crítica frankfurtiana e a consolidação da dialética negativa alheia a alguns pensadores clássicos. De fato, neste sentido, Adorno (1965) revela uma visão interdisciplinar no âmbito da teoria frankfurtiana (Nobre; Marin, 2012). Na concepção adorniana, apenas com um trabalho conjunto, de todas as ciências sociais, seria possível compreender os processos sociais e as atitudes alienantes inerentes à dinâmica subjetiva. Seria impossível conceber a dialética negativa se negligenciadas teorias fundamentais que a consolidam, para além do materialismo marxiano, do positivismo comteano e do idealismo hegeliano (Zanolla, 2007). Assim, a priori, desmistifica-se certa dicotomização extremista acerca das contradições entre o materialismo e o idealismo como manifestação do embate entre o universo subjetivo e o objetivo. Considerar o universo da subjetividade, bem como fatores da Psicologia para compreender processos alienantes no contexto da dialética negativa remete, inicialmente, a elaborações de Weber (1991). Para o autor, os motivos que levam às relações de dominação são administráveis e racionais (p. 139).

Segundo Adorno (1995), a filosofia de Weber - sábia e de mentalidade positiva - indica o desinteresse da ciência pela investigação além da consciência de si mesma do cientificismo. O subjetivismo weberiano, segundo Adorno, por mais que seja nominalista - um conhecimento que estima os conceitos -, possibilita apreender algo de constitutivo acima da vantagem meramente operacional (p. 160). Embora seja considerado um autor subjetivista, Weber apresenta o objeto de maneira cristalizada por excesso de definições e determinações, acumulando conceitos operativos. No entanto, sua metodologia expressa elementos centrais para a dialética negativa de Adorno, por exemplo, no que se refere ao conceito de capitalismo, que é decisivo em todos os sentidos: em Weber é distinto de categorias isoladas e subjetivas com tendência a adquirir o desejo do lucro e, neste ponto, deixa-se captar pelo conceito histórico materialista (p. 164). Isso traz a alienação como base do conteúdo ideológico. O mérito de Weber está na sua contradição: "Precisamente assim, acredita-se ser o seu pensamento como um tertium, por 
cima da alternativa entre positivismo e idealismo" (p. 169). Não por acaso, em Weber, configura-se uma ação moderna, influenciada pelo pensamento clássico kantiano.

Reconhecer o papel da subjetividade para consolidar o materialismo exige traduzir as contradições da razão explicitadas no prefácio da obra "Crítica da Razão Pura", a princípio, aparentemente alusiva ao pragmatismo: "Tão só o resultado possibilita de imediato julgar se a elaboração dos conhecimentos pertencentes aos domínios próprios da razão segue ou não o caminho seguro da ciência" (Kant, 2003, p. 25). Essa contradição do pragmatismo é elemento significativo na consolidação do conceito de dialética negativa. Para Adorno, a obra kantiana leva a uma ética, que, embora contraditória - pelo risco de determinar uma espécie de "dialética da vontade" -, permite uma resistência imanente ao sujeito: "Toda a ética kantiana adoece por não permitir a razão como um motor da prática. Isso a faz permanecer abaixo da fascinação do pálido teoricismo contra o que discorreu de modo complementar ao primado da razão prática", [...] ou "A lógica é uma práxis impermeabilizada contra si mesma" (p. 229). A crítica da razão pura parte tanto da/pela razão, como contra a razão. Apresenta-se como possibilidade concreta de abstração da realidade tal qual é dada a conhecer: contradição. O comportamento do sujeito em relação ao objeto é contraditório, porém, somente sua limitação pode indicar ampliação (Zanolla, 2007).

Para Adorno (1984), vulgares interpretações do pensamento kantiano apontando-o como abstracionista subtraem o que de mais importante sinaliza: a possibilidade de transcender o fator subjetivo do pesquisador na relação com o objeto. As contradições do pensamento kantiano, os equívocos de sua interpretação e a crítica traduzindo-o apenas como sendo de caráter abstracionista no trato com o conhecimento, bem como o contexto do ideário liberal e a ascensão dos valores iluministas fizeram com que, em geral, na modernidade, os críticos recebessem positivamente as contribuições de Hegel, outro importante pensador, para a teoria crítica. Para Adorno, "O que para Hegel e Marx foi insuficiente teoricamente se comunicou à práxis histórica" (1984, p. 148). Por mais que a dialética hegeliana possa ser injustamente relegada pelos militantes do materialismo ao lugar comum do idealismo vulgar que incoerentemente a positiva; negar, de algum modo, a importância de Hegel na elaboração do pensamento dialético é impraticável:

Crítico da separação kantiana de conteúdo e forma; quer Hegel, uma filosofia sem forma independizada, sem um método a manipular com independência da coisa; e, no entanto, procedeu metodicamente. A dialética não é de fato nem só método nem tampouco algo real entendido ingenuamente. [...] A dialética como procedimento 
significa pensar em contradições a causa da contradição experimentada na coisa e contra ela. Sendo contradição em realidade é também contradição na realidade. Porém esta dialética não é conciliável com Hegel. Seu movimento não tem a identidade da diferença de cada objeto com seu conceito, mas, desconfia do idêntico (Adorno, 1984, p. 148).

A formulação consistente da dialética social material deve-se à agregação do fator histórico como desdobramento da fenomenologia de Hegel (Marx, 1982). Apesar de suas contradições no âmbito da fenomenologia, o idealismo hegeliano foi um determinante para desmistificar a realidade. Em Hegel, a consciência não é pressuposta e, sim, coloca-se em movimento pela experiência. Segundo Adorno (1984), o problema de Hegel reside em que o sentido da totalidade volta-se para a liberdade de acordo com o ideal racional, o que o torna, contraditoriamente, voltado para o teor afirmativo do conhecimento. Ainda assim: "A única forma de escapar ao confinamento do idealismo é de dentro deste, chamando-o por seu nome a repetir seu próprio proceder dedutivo e demonstrando sua desunião e falsidade em desapego à ideia de totalidade" (Adorno, 1984, p. 149).

Para Adorno (1984), o mérito de Hegel - bem como sua ruína - foi tentar conciliar filosofia e experiência com a sociedade real. Apesar de traduzir uma filosofia da ação, um dos problemas reside em que, mediante o pensamento crítico, o indivíduo tende a se cristalizar no contexto da história, arriscando determinar sua existência (Hegel, 1999, pp. 223-236). Se assim o for, ocorre a idealização da história, pois o próprio Hegel atestava a supremacia da verdade sobre o fator histórico, como era prenunciado por Marx: "Marx não só denuncia a transfiguração que Hegel opera, senão também a realidade a que se aplica. A história humana como história de um crescente domínio da natureza prossegue a inconsciente história natural, a devorar e ser devorado" (Adorno, 1984, p. 354).

A ascendência do pensamento marxista na teoria crítica, sobretudo na elaboração da dialética negativa, é complexa e polêmica, em particular, por três aspectos importantes. Primeiro, em relação ao que pontuou Horkheimer a certa dívida da teoria crítica para com o marxismo, no sentido da fidelidade à continuidade do pensamento dialético de Marx, longe de reafirmá-lo como incontestável (Jay, 1973); em segundo, uma questão central que passa pela epistemologia e não pode ser negligenciada: o risco de positivar a teoria marxista em nome da práxis; e, terceiro, a carência de elementos ligados ao tema da subjetividade para estudar a dominação e a alienação na perspectiva marxista (Adorno, 1955; 1973; 1984; 1995). 
Assim, a dívida com o marxismo exprime uma concepção formulada de dentro e "para" o materialismo histórico dialético; um compromisso de diagnosticar a ameaça da barbárie objetiva que possui tendências subjetivas. Mesmo que para isso fosse preciso fazer frente a concepções apaixonadas, extremistas, reformuladas ou fetichizadas dos próprios marxistas (Adorno; Horkheimer, 1985). Isso diz respeito à relação entre teoria crítica e marxismo; denuncia o perigo da positivação do método materialista em nome da idealização da práxis, discussão que envolve mediações entre objeto, sujeito e método. Para Adorno, é preciso também desmistificar o método e os conceitos marxistas (Adorno, 1984, p. 355).

Diante da complexidade, restringir a análise do pensamento marxista às relações econômicas de produção seria incoerente. Muito embora Adorno demarque um diagnóstico de perda da centralidade econômica na contemporaneidade, a apreensão da realidade com base nas categorias marxistas abrange desde o fator econômico-político às relações que perpassam a constituição e a cristalização da realidade das relações humanas. Marx (1982) compreende que objeto e método são elementos necessários e encadeadores no mesmo processo de conhecimento. As possibilidades de superação do movimento real, da ideologia, não se limitam à dimensão objetiva, aparente do objeto. Para Marx (1982), a metodologia científica compreende a essência ideológica do real e torna-se supérflua se a aparência exterior e a essência coincidirem. A existência da formulação dialética acrescida dos fatores históricos materiais deve aderir ao objeto, desmascarando seu fetichismo e contradições.

Se existe, para Marx, possibilidade de consciência em relação ao movimento do objeto e aos limites do método, qual seria então o risco de fetichização do objeto, já que o positivismo há muito é fator de critica da ciência marxista? Adorno (1995) contribui para o debate retomando que a insuficiência do pensamento marxista não está propriamente no seu método, mas, ao contrário, naquilo que ele atesta de maneira coerente, reside nos limites históricos que precedem e procedem à elaboração do método materialista dialético, lacuna referente aos processos psicossociais de constituição da subjetividade formatada pelo contexto de ampliação das relações produtivas que, por ocasião da reestruturação do sistema capitalista liberal, inaugura novos mecanismos culturais de dominação, sobretudo, a partir da Segunda Guerra Mundial. O fetichismo do método marxista não o invalida, ao contrário, fortalece os pressupostos que indicam sua razão de ser e conceber a sociedade historicamente, o que cobra uma teoria voltada para a compreensão do indivíduo, ou do pseudoindivíduo. Entretanto, a idealização do método 
marxiano dificulta apreender a própria dinâmica histórica e cristaliza a práxis. A fragilidade metodológica não está no positivismo em si (posto que este também enquadra pressupostos materialistas), mas em qualquer conhecimento que se positiva (mitifica).

O aspecto positivo não está na teoria positivista em si (pois, quanto a isso, ela cumpriu seu papel de teoria legitimadora da ciência), mas na renúncia em considerar as contradições envolvidas no seu próprio arcabouço teórico (Comte, 1996). Para a teoria crítica, este conhecimento tradicional sintetiza a pretensão conservadora de generalizar e especializar o saber como fim; o que fez com que houvesse uma conciliação dos aspectos universais e particulares, redundando numa espécie de totalitarismo do conhecimento, privilégio não apenas do positivismo clássico, como de toda a ciência - sobretudo, daquela que mais se julga livre da contradição. Neste ponto, coloca-se a questão da positivação do marxismo via sua vulgarização ou, como preferiria Adorno (1984), no "fanatismo pela dialética". Daí advém a proposta de estudar não apenas possibilidades filosóficas da dialética negativa, mas as condições reais de possibilidades no sentido imanente (Nobre, 1999).

Uma das principais contribuições da Escola de Frankfurt ao marxismo com base em Weber, Hegel e Kant é mostrar que as complexas relações de dominação social, no aspecto subjetivo, não são contempladas por meio da categoria de mediação (Zanolla, 2012). A mediação, apresentada como um fenômeno que leva à conscientização, pelos psicólogos sociais, desprovida do seu caráter dialético negativo, ou seja, do reconhecimento do potencial idealista e fetichizante da dialética materialista, representa uma análise totalitária das relações sociais e da práxis. Uma traidora conciliação entre o universal e o particular (Zanolla, 2012). Essa mediação ilusória concilia positivamente sujeito e objeto, uma relação abstrata que sela o "conformismo do todo" (Adorno, 1995). Daí a necessidade de reconhecer a primazia do objeto, contraditoriamente, com base no retorno ao pensamento kantiano, uma retomada do que denomina Adorno (1995) de Giro Copernicano.

A ideia do giro copernicano promove uma reviravolta epistemológica na teoria de Adorno e redimensiona o lugar da subjetividade na teoria marxiana; razão pela qual o autor centra esforços na tentativa de compreender os limites subjetivos ao potencial crítico e revolucionário da humanidade. $\mathrm{O}$ giro copernicano repõe a complexa relação entre materialismo e idealismo em um conjunto que possui como núcleo a retomada do mundo sensível kantiano. É a retomada da subjetividade contra ela mesma. Isso configura emergir o reducionismo e a inversão da dialética materialista ao abstracionismo da mediação social objetificante. Se assim o for, na perspectiva da dialética 
negativa, a dialética materialista foi traída pelos seus fiéis adoradores ao ignorarem o potencial conformista pela subjetividade esquecida em nome da objetividade sonhada. Todavia, recorrer à subjetividade para compreender o processo alienante não impede que, em Adorno, prevaleça o princípio sócio-histórico marxiano de vislumbrar a superação: do sujeito, espera-se consciência, do objeto, não (Adorno, 1995).

O raciocínio marxiano preconiza a dialética entre o homem e a sociedade em uma dinâmica complexa: "Portanto, pensar e ser são decerto diferentes, mas, simultaneamente estão em unidade um com o outro" (Adorno, 1995, p. 95). O próprio Marx (1982), em "O capital”, alerta para dificuldades encontradas por alguns intelectuais em entender a mediação perpassada pelo seu método: "O método empregado nesta obra, conforme demonstram as interpretações contraditórias, não foi bem compreendido" (p. 173). Desmistificar o conhecimento configura prática do próprio Marx (1982) em relação ao seu "mestre" Hegel. Assim, reconhece a importância da filosofia alemã, alegando que os limites relativos ao conceito de dialética na fenomenologia não impediram a Hegel ser o primeiro a elaborar suas formas gerais do movimento, com vistas à consciência. De certa forma, Marx sente-se na obrigação de desmistificar a obra hegeliana para desmistificar a sua própria. "Em Hegel, a dialética está de cabeça para baixo. É necessário pô-la de cabeça para cima, a fim de descobrir a substância racional dentro do invólucro místico" (p. 176). O caráter revolucionário, ao tempo que contraditório de Marx em relação a Hegel, não foi ignorado por Adorno: “A teoria marxiana da unidade valia para o agora ou nunca, talvez a partir do pressentimento de que, de outro modo, poderia ser tarde demais. [...] O pudor de Marx perante as receitas teóricas para a práxis, mal foi menor que o de descrever positivamente uma sociedade de classes" (Adorno, 1995, p. 228).

A contribuição marxista para a teoria do conhecimento e para a ação social não está em questão para a dialética negativa na teoria crítica frankfurtiana, mas sua insuficiência em relação às formas de apreensão que acabam contribuindo com a manutenção do poder por meio de contradições dos mecanismos culturais de dominação que fetichizam a práxis e a dialética materialista, sim (Adorno, 1994b). Isso justifica os argumentos de Nobre (1999) acerca da importância de se reunirem forças interdisciplinares no arcabouço da teoria crítica frankfurtiana. Não obstante, corrobora também o reconhecimento da importância de diversas áreas científicas ligadas ao estudo do indivíduo, para melhor entender a alienação e a resistência dos aparelhos ideológicos; este foi outro motivo pelo qual a teoria crítica ampliou seus termos de referência e buscou, na psicanálise, preencher lacunas referentes 
ao funcionamento psíquico. A psicanálise é mais que uma alternativa à psicologia na compreensão do senso crítico da dialética negativa; retoma o giro copernicano, referindo-se à necessidade de se voltar para a compreensão do sujeito para entender o universo objetivo, material, ou seja, kantianamente "a volta ao sujeito no seu contrário" (Adorno, 1995, p. 202).

Em que pese sua importância, a psicanálise não é imune à crítica adorniana; compõe o arcabouço adorniano como elemento que denuncia contradições e também arrisca definições abstratas acerca do indivíduo, entretanto, "é a única que investiga a sério as condições subjetivas da irracionalidade objetiva" (Adorno, 1955, p. 136). A crítica em relação à identidade do sujeito idealizada e mediada socialmente, e, ainda, a ideia do aparelho psíquico regido por uma dinâmica conflituosa que liga o (in)consciente à ideologia, fez com que a possibilidade de tencionar as instâncias objetiva e subjetiva se tornasse mais real. Assim, a intenção da concepção dialética negativa de sanar a dívida com o marxismo, no que tange à subjetividade, "só poderia ser concretizada com uma abordagem tão controversa quanto insuficiente como a psicanalítica" (p. 136-138). Em psicanálise, o conflito entre id (fator externo/social) e ego (fator interno/individual) é identificado como possibilidade de lidar com o universo subjetivo, de maneira que este não seja mecanicamente submetido ao universo objetivo (alienante), e, sim, reconhecido dialeticamente em meio a ele. A preocupação de Freud (1973b) com a contradição da civilização - o progresso desumano -, ligada ao desenvolvimento técnico e suas dificuldades para domar os instintos agressivos, foi amplamente explorada no conjunto das obras de Adorno e Horkheimer. Entretanto, é digna de nota a advertência de Nobre e Marin (2012):

Para além da já mencionada diferença de estrutura - Horkheimer e Adorno desenvolvem uma teoria da mimese e não uma teoria das pulsões, o que está longe de ser um problema meramente terminológico -, pode-se pensar em uma série de outras diferenças analíticas relevantes, como o papel de grande destaque concedido ao "terror" quando comparado ao esquema freudiano, o que acarreta arquitetônicas pulsionais bastante diversas. Se Horkheimer e Adorno pretendem responder a problemas de inspiração freudiana, partem também do pressuposto de que a teoria freudiana sozinha não é capaz de respondê-los, ao mesmo tempo em que a tradução das constelações conceituais freudianas em teoria social tem ao final por resultado uma radical transformação desse ponto de partida (p. 120).

Daí a importância do caráter dialético, histórico e antropológico, proveniente da psicanálise crítica. Ao investigar as sociedades primitivas, Freud (1973a) considera o aspecto sociológico por "contorno definido": "Toda a história da civilização é uma exposição de estradas que empreendem homens para dominar os seus desejos não realizados, de acordo com as exigências 
da realidade" (p. 1864). Esse contorno permite aos estudiosos da psicanálise aproveitar intensamente essa rica relação da psique com a realidade social. O próprio autor afirma que o desaparecimento do fator social e o predomínio do fator sexual convertem as soluções neuróticas em caricaturas inutilizáveis para a resolução dos problemas do homem, acrescentando que: "A psicanálise tem como objeto a psique individual, mas seu trabalho não pode abrir mão dos fundamentos efetivos da relação entre indivíduo e sociedade" (p. 1865).

É claro que a preferência pela psicanálise como método psicológico não contemplou unicamente os esforços de entender a sociedade vigente, tanto que na obra "La personalidad autoritária", Adorno (1965) utilizou uma metodologia com conceitos e análises psicanalíticos, sem negligenciar a contribuição da psicologia tradicional. Embora o foco fosse o aspecto sociopolítico totalitarista, a cultura, os grupos, as atitudes políticas e a ideologia coletiva, era no comportamento individual que o estudo buscava suas respostas. Isso é importante para elucidar elementos que levam a ações tolerantes ou intolerantes em determinadas situações de alienação e, ainda, entender em que medida certos conflitos de grupos políticos - que aparentemente possuem diferenças sociais -, em nome da práxis ou não, derivam de fatores semelhantes em âmbito externo e interno, constituindo-se em ações autoritárias ou emancipatórias.

Devido à abordagem desmistificadora, a psicanálise denuncia o perigo da conciliação simbiótica (psicótica) entre indivíduo e sociedade, sujeito e objeto, ou a perda do universo subjetivo na absorção do universo objetivo, efeito que demonstra uma conduta narcisista, postulando a idealização do ego pela supervalorização das ideias, da própria práxis e do sujeito (Adorno, 1955; 1995). Retoma-se assim, psiquicamente, pelo princípio da não identidade (sujeito neurótico e autocrítico), a dialética entre alienação e consciência, preconizada teoricamente pela dialética negativa (1995, p. 89). O sujeito egocêntrico é o homem indiferenciado, onipotente, narcisista, voltado para si em busca de uma identidade cristalizada, ilusória e prepotente. Essa idealização é, segundo a teoria crítica, insustentável, porque traduz o sujeito voltado para o instinto primário, cujo objetivo principal é a satisfação instintual de necessidades mais imediatas: "Os objetivos são idênticos aos objetivos instintivos primários, e não pode ser traduzido para contradizê-los em muitos aspectos" (Adorno, 1995, p. 153).

Assim, uma vez que o repertório teórico dos frankfurtianos tem na concepção do materialismo dialético um de seus principais embasamentos para o trabalho enquanto experiência, o sócio-historicismo vulgar é denunciado pela dialética negativa por cegar a práxis e arriscar sobrepujar o próprio marxismo do ponto de vista político e conceitual. 


\section{Dialética Negativa e Dialética Materialista - problema e método}

Segundo a teoria crítica adorniana, qualquer conhecimento, seja relacionado ao método científico ou à filosofia, possui em si uma "representação preliminar", implica repetição do instrumento ou do pensamento. Para Adorno (1994a), "Há muito as reflexões críticas sobre o instrumento têm deixado de afetar o objeto do conhecimento científico, para limitar-se simplesmente a ser acessível a todo o conhecimento: à validez dos juízos científicos" (p. 76). Assim, tratar um problema nascido de um pressuposto filosófico específico presume uma lógica não menos importante do que analisar as condições de validade dos procedimentos de investigação do saber científico.

Segundo Abbagnano (1998), o que demarca a interpretação da metodologia como conhecimento está na lógica pós-cartesiana. Gerado na sociedade renascentista, o método cartesiano merece ser destacado ao se discutirem os fundamentos que justificam a dialética negativa por, classicamente, "tentar bem conduzir a razão" e procurar a "verdade" nas ciências, em um momento em que a Escolástica dominava o cenário intelectual. O pensamento naturalista e "aplicável" de Descartes demonstra uma relação inseparável com o objeto, o que o torna idealista.

Horkheimer (2000) assinala que "os problemas epistemologicamente insolúveis do espírito se fazem sentir em todas as formas de idealismo" (p. 173). Ainda assim, algumas restrições a especulações míticas acerca do significado do espírito podem transformar o seu objeto em abstração do real. "A saída para esse problema seria enfrentar a contradição do dualismo entre natureza e espírito" (p. 174). Para Adorno (1995), o "homem divino", o sujeito cartesiano, carrega em si a contradição de "responder à sinistra pergunta de como se pode pensar, e ainda assim seguir vivendo: pelo fato de se pensar" ( $p$. 23). Isso dito de forma extrema seria: "Eu não penso, e até isto é pensar" (p. 24). Esse paradoxo põe, mais uma vez, a dualidade universal versus particular. A partir daí, tanto a epistemologia como a ciência meramente empírica tornamse tão necessárias quanto insuficientes para a teoria crítica.

Em consonância com a defesa da dialética negativa, e denunciando o "materialismo da imediatez", Adorno refere-se à Sociologia como uma área que deixa a desejar do ponto de vista dos estudos acerca do caráter subjetivo da alienação: "A dialética não é sociologia do saber" (1984, p. 195). Em 1968, Adorno participou do $16^{\circ}$ Congresso de Sociologia Alemã, no qual tratou, segundo ele, de um problema epistemológico: saber se a atual fase (após a Segunda Guerra Mundial), consonante ou não com os princípios marxistas, deveria chamar-se Capitalismo Tardio, ou Sociedade Industrial (Adorno, 1994b, p. 62). O autor desmistifica, ali, duas ideias vulgares: a 
teoria crítica confronta-se diretamente com o marxismo, e esta é pessimista em relação à revolução social. O fato é que, após a Segunda Guerra Mundial, a reestruturação do papel do Estado, da indústria e do mundo do trabalho implicou modificações na estrutura das classes sociais - principalmente nos países ocidentais (Ianni, 1993). Isso configurou um problema para o método de Marx: será que as relações de produção se revelaram mais potentes do que este previra?

Para Adorno (1994b), os métodos empíricos de análise acerca do problema são sempre insuficientes assim como o modo que o objeto de Marx era bem delineado pelo contexto político, histórico e social. O problema não está na pesquisa objetiva e materialista, mas no seu não aprofundamento, que, cego pelo dogmatismo otimista, perde de vista a própria dialética a que veio. Prova disso é que, à parte o desenvolvimento da civilização, as contradições sociais demonstram que a globalização da sociedade permanece fiel à dominação totalitária denunciada por Marx desde os primórdios: "A consciência reificada não termina onde o conceito de reificação ocupa um lugar de honra" (Adorno, 1994b, p. 69). A teoria psicanalítica mais uma vez pode contribuir para o entendimento desse dilema.

A consciência não é uma aquisição permanente, pelo contrário, na perspectiva freudiana, sua existência, entre outras coisas, depende da luta pulsional individual estendida coletivamente, na negação e afirmação do ego, instância dominada ao tempo que negada, conflito necessário consciente elaborado da satisfação plena, integral; interditada pelas normas sociais; isso requer reconhecer no processo pulsional uma dinâmica dialética. Assim, Freud contribui para a desmistificação do homem/sujeito e consequentemente, segundo Adorno, para o esclarecimento das contradições da práxis. Melhor dizendo, para ele, a identidade do sujeito só existe na afirmação e negação do que ela poderá vir ou não a ser de acordo com condições diversas: é bom que se diga que o sujeito consciente (de modo permanente) consiste em fantasia. Reconhecer isso é condição para a autoemancipação do sujeito. Essa dialética negativa, no plano subjetivo, apresenta ao sujeito a consciência da realidade e sua positividade; a precária liberdade que, limitada e ilusória, pode levar ao reconhecimento da repressão e também: "Fazer algo libertador positivo, pois, como um dado ou como inevitável entre outros dados, é imediatamente oposto a convertê-lo a si" (Adorno, 1994a, p. 231). Por isso, o objeto se sobrepõe ao sujeito, pelo fato de este ser dominado, alienado pela realidade objetal.

Adorno e Horkheimer (1985) concordam que a positividade pode ser dupla, ou seja, não apenas do conhecimento científico tradicional, mas de interpretações vulgares da dialética materialista. Para os autores, o 
totalitarismo é um conceito que merece destaque, seu caráter universal satisfaz teórica e empiricamente as necessidades apriorísticas da positividade, de maneira a adaptar teoria e prática à política do nacionalismo exacerbado, ao comportamento violento e preconceituoso; tanto o conceito quanto a ação levam à ofuscação da realidade, impedindo a transformação. Nessa perspectiva, há que se fazer justiça ao pensamento marxista, denunciando o perigo de positivação da própria dialética. Para Adorno:

Em certo sentido, a lógica dialética é mais positivista que o positivismo, apesar do desprezo em que este a tem, já que respeita como pensamento o que há que pensar o objeto, inclusive quando este não se apega às regras mentais. Estas mesmas ficam afetadas pela análise do objeto. O pensamento não necessita ater-se exclusivamente à sua própria legalidade, senão que pode pensar contra si mesmo sem renunciar à própria identidade. Se fosse possível uma definição da dialética, poderia ser esta (Adorno, 1984, p. 144).

O autor afirma que a dialética não é apenas um método, tampouco algo material entendido ingenuamente, de maneira abstrata. A dialética além do procedimento significa pensar contradições sobre a causa da contradição experimentada na e contra a coisa, sendo contradição da realidade e contradição pela realidade (p. 148). Demonstrar apenas teoricamente o caráter negativo da dialética é correr o mesmo risco de alguns marxistas ao criticar o idealismo em nome da prática, tendo como base o materialismo. Pode-se transformar a dialética em um método meramente aplicável, um modelo; ou, em um segundo caso, pode-se resumi-la em teoria - contra a teoria - pelo idealismo em nome da prática e contra a experiência. É assim que a totalidade se inverte conceitual e materialmente pelo absolutismo do totalitarismo. A crítica neoliberal feita ao liberalismo demonstra essa inversão da contradição no âmbito estrutural e político. Nesse caso, o sistema apropria-se da própria crítica contra ela, negligenciando o aspecto histórico, ou contextual do problema (Paulo Neto, 1999).

O fato de Adorno criticar a conciliação conceitual ou metodológica entre teoria e prática não significa que abra mão do método, do conceito, ou da técnica, mas mantém-se fiel à própria contradição da práxis. Nesse caso, "A crítica negativa deve preparar um conceito positivo do esclarecimento, que o solte do emaranhado que o prende à dominação cega, mesmo que, para isso, tenha que tomar consciência de si mesma, se os homens não querem ser completamente traídos" (Adorno; Horkheimer, 1985, p. 15). A crítica deve ser feita reciprocamente (sujeito e objeto), considerando kantianamente as possibilidades limitantes do julgamento ideológico da própria análise do sujeito para com o objeto. Assim, enxergar o fenômeno weberianamente como 
um "ser objeto" torna-se (im)possibilidade metodológica. Contraditoriamente, o oposto da crítica também é verdadeiro: tal a complexidade da inversão do problema, que os motivos para o não reconhecimento das contradições do conceito de práxis estão na extrema defesa de seu sentido negativo que, segundo Adorno (1984), residem no equívoco de absolutizar a teoria, ou acusála de anacrônica e insuficiente, retirando sua base histórica e dialética. A única maneira de lutar contra o pensamento afirmativo é descortiná-lo mediante sua aparência; demonstrar a própria condição falsa de ser um pensamento teórico edificante (Adorno, 1995, p. 45).

Essa discussão demonstra que, se existe alguém esperando ancorar-se em lições para o entendimento de um "método perfeito" referente à dialética negativa, perde seu tempo. Pelo bem da prevalência do instinto vital humano (a elaboração do conflito eterno), o "remédio", como diria Adorno (1994b), ainda não foi encontrado. "Eis aí a esperança tão cobrada aos frankfurtianos pelos positivadores do conhecimento, materialistas ou idealistas. Se os dogmáticos da teoria do conhecimento ainda não perceberam o sentido do totalitarismo em oposição ao universal, não será uma ou outra teoria a responsável por isso talvez a composição de todas" (Zanolla, 2007, p. 77).

Diante de tais pressupostos, permanece a ideia de que a dialética negativa persegue um projeto ou método inacabados. Se em Marx, originalmente, podese identificar uma "dialética objetiva e imanente" (Adorno, 1984, p. 198), a objetividade como mediação para a consolidação da subjetividade emancipada é representada na indigência racional do homem perante a sociedade. Em que pese isso, a possibilidade de romper com a falsa consciência está na desmistificação do próprio conceito de dialética enquanto "método perfeito da experiência ideal"; o que ampliaria possibilidades de denunciar uma prática a qual adialeticamente se reflete uma situação delirante da objetificação humana, persistente e definida por Adorno (1995) como "eu epistemológico".

\section{Referências}

ABAGNANO, N. "Dicionário de Filosofia". São Paulo: Martins Fontes, 1998.

ADORNO, T. "De la Relación entre Sociología y Psicologia". In: Actualidad de la filosofia. Barcelona/Buenos Aires: Paidós, Col. Pensamiento Contemporâneo, 1955.

. "La personalidad autoritária". Buenos Aires: Proyección, 1965.

“Temas básicos de Sociologia”. São Paulo: Cultrix, 1973.

"Dialectica Negativa". Madrid: Taurus, 1984.

"Introducción a la Sociología". Barcelona: Gedisa, 1994a.

"Sociologia”. São Paulo: Ática, 1994b.

"Palavras e sinais - modelos críticos 2". Petrópolis: Vozes, 1995. 
ADORNO, T., HORKHEIMER, M. "Dialética do Esclarecimento". Rio de Janeiro: Zahar, 1985.

COMTE, A. "Coleção Os Pensadores". Biografia. Rio de Janeiro: Nova Cultural, 1996.

DESCARTES, R. "Discurso do Método". São Paulo: Martins Fontes, 2003.

FREUD, S. (1914). "Totem e Tabu”. Tomo II, Obras completas. Madrid: Biblioteca Nueva, 1973a.

. (1914). "O Mal estar na Cultura". Tomo III, Obras completas. Madrid:

Biblioteca Nueva, 1973b.

HEGEL, F. “Coleção Os pensadores”. Bigrafia. São Paulo: Nova Cultural, 1999.

HORKHEIMER, M. "Eclipse da Razão". São Paulo: Centauro, 2000.

IANNI, O. "Teorias da globalização". Rio de Janeiro: Civilização, 1993.

JAY, M. "La Imaginación Dialectica - Historia de la Escuela de Frankfurt y el Instituto de Investigación Social". Madrid: Taurus, 1973.

KANT, I. "Crítica da razão pura". São Paulo: Martin Claret, 2003.

MARX, K. “O capital”. São Paulo: Global, 1982.

MARX, K., ENGELS, F. “Ideologia alemã”. São Paulo: Hucitec, 1999.

NOBRE, M. “A Dialética Negativa de Theodor W. Adorno". São Paulo: Iluminuras, 1999.

NOBRE, M., MARIN, I. L. "Uma nova Antropologia. Unidade Crítica e Arranjo Interdisciplinar na Dialética do Esclarecimento". Cadernos de Filosofia Alemã, São Paulo, Nr. 20, 2012.

PAULO NETO, J. P. “Ofensiva Neoliberal”. São Paulo: Cortez, 1999.

SILVA, E. S. "Coerência em suspensão: Adorno e os modelos de pensamento". Artefilosofia, Ouro Preto, Nr. 7, pp. 55-76, out./2009.

WEBER, M. "Economia e Sociedade". Vol. I e II. Brasília: Ed. UnB, 1991.

ZANOLLA, S. "Teoria Crítica e Epistemologia: o método como conhecimento preliminar". Goiânia: PUC, 2007.

. "O Conceito de Mediação em Vigotski e Adorno". Psicologia e Sociedade,

Belo Horizonte, Vol. 24, Nr. I, pp. 398-419, jan./abr. 2012. 